\title{
AOR
}

Selected Papers of \#AolR2019:

The $20^{\text {th }}$ Annual Conference of the Association of Internet Researchers Brisbane, Australia / 2-5 October 2019

\section{THE BIRDS AND THE BEES ONLINE: UNDERSTANDING AMERICAN ONLINE SEX-} ED SITES

\author{
J. Nalubega Ross \\ Arizona State University \\ Shawn Walker \\ Arizona State University
}

The goal of this study is, using twitter and looking over time, what is the nature of the content of adolescent sexual health education provided by sexual health education organizations. Sexuality is a critical component of adolescent development, and to aid in sexual development, the United Nations Educational, Scientific and Cultural Organization (UNESCO), and the World Health Organization (WHO) recommends that adolescents globally have access to comprehensive sexual health education because it contributes positively their future sexual and reproductive health (UNESCO, 2018). In the United States, starting in 1981 with Adolescent Family Life Act (AFLA) sexual health education has relied heavily on Abstinence-Only curricula, with the goal of teaching adolescents to reduce risky sexual behaviors, such as having unprotected sex, having multiple sexual partners and young age of sexual debut by remaining sexually abstinent until marriage (Dixon-Mueller, 1993; Saul, 1998). A review of sexual health education programs by the American Council on Science and Public Health (2009) found a lack of strong evidence showing that abstinence only programs kept youth abstinent until marriage or reduce number of sexual partners.

Ten years after this report, funding continues to be funneled into abstinence only education curricula, curricula that have been criticized for being heteronormative, excluding sexual minorities and promoting rigid gender roles (Fine, 1988; Fine \& McCLELLAND, 2006; Freeman, Caldwell, Bennett, \& Scott, 2018). One result of the continued use of abstinence only curricula has been a general decline in the provision of sexual health education in schools, a move that has pushed adolescents to online spaces to find sexual health education (Buhi, Daley, Fuhrmann, \& Smith, 2009; Buhi et al., 2010; Holstrom, 2015). Numerous studies have reviewed how adolescents search for sexual health information online but very few studies have interrogated the content of sexual health education online. Looking over time and on specifically on twitter, the goal of this study is to determine; 1 ). How is sexual health education on twitter Suggested Citation (APA): Ross, J. \& Walker, S. (2019, October 2-5). The Birds and the Bees Online: Understanding American Online Sex-Ed Sites. Paper presented at AoIR 2019: The $20^{\text {th }}$ Annual Conference of the Association of Internet Researchers. Brisbane, Australia: AolR. Retrieved from http://spir.aoir.org. 
structured and what topics are covered? 2). How has online sexual health education over time responded to government mandates on sexual health and sexuality in general? and 3). How do organizations using twitter handle topics such pleasure and desire for underrepresented groups?

To respond to the decline in sexual health education in schools, numerous organizations have created sites such as sexetc.org and scarleteen.com as an avenue to provide sexual health information to American adolescents. Sexetc for example is run by Answer, an organization that "...provides and promotes unfettered access to comprehensive sexuality education for young people and the adults who teach them." (sexetc.org, 2019). Given such a claim by the organization that is running this website, it is therefore important to interrogate their twitter content and the twitter content of other similar organizations to determine whether or not it meets the international standards of comprehensive sexual health education. Social Networking Sites (SNS) like twitter are an avenue that organizations have used to provide sexual health education for adolescents because adolescents, who usually have limited access to public spaces use these sites to maintain and collate social relationships (boyd, 2014). Adolescents are especially attracted to online spaces for their sexual information needs because of the perceived privacy and the confidentiality afforded to them in online spaces. And though adolescents enjoy this privacy they still crave social interaction when it comes to sexual health education (Holstrom, 2015).

A 2018 survey by the Pew Research Center (2018) found the of the popular social media sites among 13-17year old adolescents YouTube was the most popular, followed by Instagram, Snapchat, Facebook, and Twitter. The study found that though majority of adolescents were using YouTube, adolescents from low-income households tended to use Facebook more than the other four sites and female adolescents using Snapchat as their go-to social networking sites (Pew Research Center, 2018). Given the gender and economic differences in use of social networking sites and the different affordance of each SNS, it becomes important to look across different social networking sites to see how sexual health education changes across SNS and how those changes have occurred over time. Using twitter, the goal of the present study is to determine how sexual health education changes between the organizations and over time.

Michelle Fine in 1988 argued that sexual health education in America portrayed adolescent women as victims of potential male predators, with women having the undue burden of having to say no, and guard against being used (Fine, 1988). Sexual health education in America was able to name adolescent male desire but girls are taught to not recognize their own sexual desire, and when they recognized it adolescent women did not know how to act upon their desire (Fine, 1988; Tolman, 1994, Impett \& Tolman, 2006). Fine in 1988 offered an alternative argument where sexual health education should educate adolescent women towards sexual self-interest which would put an adolescent women in a rich and empowering environment safe to develop a sense of self that is not only intellectual, social, and economic but also sexual (Fine, 1988). Because the discourse of desire and pleasure is missing from the abstinence-only curricula, using this missing discourse provides a specific avenue to examine how 
organizations using twitter as a sexual health education site address topics such as desire and pleasure, especially for Lesbian, Bisexual, Gay, Transgender, Queer, Intersex, Asexual (LGBTQIA) adolescents.

To conclude, this study aims to review the type of sexual health education that is targeted towards American adolescents on Twitter by different sexual health organizations over time. This will provide an understanding of the type of information adolescents, especially LGBTQIA adolescents are able to access online and through SNS and if it indeed meets the standards set by the WHO and UNESCO. This study will provide an opportunity to discuss how affordances on twitter in particular affect the use of social networking sites as education tools and what are the advantages and limitations of using twitter as an educational tool.

\section{References}

boyd, d (2014). It's complicated. The social lives of networked teens. Connecticut: Yale University Press

Buhi, E. R., Daley, E. M., Fuhrmann, H. J., \& Smith, S. A. (2009). An Observational Study of How Young People Search for Online Sexual Health Information. Journal of American College Health, 58(2), 101-111. https://doi.org/10.1080/07448480903221236

Buhi, E. R., Daley, E. M., Oberne, A., Smith, S. A., Schneider, T., \& Fuhrmann, H. J. (2010). Quality and Accuracy of Sexual Health Information Web Sites Visited by Young People. Journal of Adolescent Health, 47(2), 206-208. https://doi.org/10.1016/j.jadohealth.2010.01.002

Dixon-Mueller, R. (1993). The Sexuality Connection in Reproductive Health. Studies in Family Planning, 24(5), 269. https://doi.org/10.2307/2939221

Fine, M. (1988). Sexuality, Schooling, and Adolescent Females: The Missing Discourse of Desire. Harvard Educational Review, 58(1), 29-54. https://doi.org/10.17763/haer.58.1.u0468k1v2n2n8242 
Fine, M., \& McCLELLAND, S. (2006). Sexuality Education and Desire: Still Missing after All These Years. Harvard Educational Review, 76(3), 297-338. https://doi.org/10.17763/haer.76.3.w5042g23122n6703

Freeman, J. L., Caldwell, P. H. Y., Bennett, P. A., \& Scott, K. M. (2018). How Adolescents Search for and Appraise Online Health Information: A Systematic Review. The Journal of Pediatrics, 195, 244-255.e1. https://doi.org/10.1016/j.jpeds.2017.11.031

Holstrom, A. M. (2015). Sexuality Education Goes Viral: What We Know About Online Sexual Health Information. American Journal of Sexuality Education, 10(3), 277294. https://doi.org/10.1080/15546128.2015.1040569

Impett, E. A., \& Tolman, D. L. (2006). Late Adolescent Girls' Sexual Experiences and Sexual Satisfaction. Journal of Adolescent Research, 21(6), 628-646. https://doi.org/10.1177/0743558406293964

Pew Research Center (2018). Teens, Social Media \& Technology 2018. Retrieved from PI_2018.05.31_TeensTech_FINAL.pdf

Sexetc.org (2019). About sexetc.org. Retrieved from https://sexetc.org/about

Saul, R. (1998). Whatever Happened to the Adolescent Family Life Act? The Guttmacher Report on Public Policy, 3.

United Nations Education, Scientific and Cultural Organization (2018). International technical guidance on sexuality education. An evidence-informed approach. Retrieved from https://unesdoc.unesco.org/ark:/48223/pf0000260770 